\title{
The Regulation of Over-Indebtedness of Consumers in Europe
}

\author{
Hans-W. Micklitz
}

Published online: 9 October 2012

(C) Springer Science+Business Media New York 2012

The economic crisis has fueled the debate on regulated state insolvencies. While debt relief is being considered for some states, citizens in some cases live their whole lives in debt. In some countries like Bulgaria, Italy, Croatia, Lithuania, and Poland, there are no consumer bankruptcy procedures which provide for an exemption from residual debt. In Spain, private debtors are entitled to debt relief on a maximum of only $50 \%$ of their debt and in other countries long periods of differing lengths are needed until complete exemption from remaining debt is granted. The length of time that information in which the publication of consumer bankruptcy notifications in public or private registers can be published also varies. There are thus no uniform regulations on how private individuals can make a clean financial start in Europe, and debtors and creditors have different opportunities. The differences in the level of protection entices insolvency tourism, which, however, is open only to those consumers who have remaining resources and who are capable of engaging in the organization of transborder debt relief. Poorer consumers are dependent on their national insolvency regime, if indeed there is any.

The European legislator has done next to nothing to get to grips with over-indebtedness from a European perspective. So far, the European approach is limited to opening up consumer credit markets. The whole EU rhetoric is very much based on the idea that consumer credit is a source of income which could and should be used. The official documents might be read so as to entice consumers and credit institutions in particular in countries with a low total number of credits to engage in credit transactions. The dark side of consumer credit, i.e., delayed payments, the percentage of interest rates, compound interests, indebtedness, over-indebtedness, or insolvency, has not gained much attention at the EU level. To be sure, there are policy recommendations to fight social exclusion, and there are also more specific recommendations related to consumer over-indebtedness. However, none of these initiatives has led to concrete regulatory steps aimed at closing the gap between intensive regulatory attempts to open up the credit market and the social consequences in circumstances where the consumer is unable to satisfy a creditor. This is all the more

H.-W. Micklitz ( $\bowtie)$

Law Department, European University Institute, Via dei Roccettini 9, 50014 San Domenico di Fiesole, Italy e-mail: hans.micklitz@eui.eu 
amazing as the EU legislator has been much more proactive in other regulated markets, such as telecommunication or energy, where at least some sort of social regulation was introduced to smooth the harsh effects of market liberalization. The only regulatory tool that is designed for insolvency, not consumer insolvency in particular, is the European Insolvency Regulation, which focuses on jurisdictional issues. In this regulation, the prevailing substantive differences between Member States insolvency regimes clash and the ECJ, under the disguise of mere procedural rules, decides de facto, not de jure, the relevant jurisdiction and the applicable law.

The major problem in Europe is the difference between Member States that have introduced consumer insolvency legislation and those that have not. A European rule could at least provide for some minimum standards, which would establish a common platform whilst leaving room for deviating standards in the Member States. It is hard to imagine that the 27 Member States are willing to agree on a compromise between the Anglo-American and the continental philosophy. The first stands for an easy fresh start; the second for a morally loaded long-lasting procedure, which allows for a fresh start but only after a period of distress and sanction. That is why it is fair to say that the standard moral debate on consumer bankruptcy proceedings ranges between two extremes, i.e. from attaching individual blame for debt to expropriation of creditors.

This brings us to the empirical side of consumer insolvency. Here, we are only at the beginning of the debate. Currently, we do not have a common definition of overindebtedness, which renders any comparison between different Member States difficult. We know that divorce and unemployment is often the reason that the consumer runs into economic difficulties. But we know rather little about the concrete social circumstances in which over-indebtedness and insolvency is embedded. A stronger European commitment, even without pre-committing to regulatory means, would certainly contribute to improve our knowledge on the potential effects of credit defaults in the Member States. It would give over-indebtedness a human face in that consumers in difficulties turn from statistical figures into human beings. Viewed in this light, empirical research is needed, but not in the form of the methodologically highly doubtful impact assessments on which the European Commission is basing its policy initiatives.

This special issue is meant to push the existing debate in Europe on consumer overindebtedness one step further. Iain Ramsay presents the different consumer insolvency regimes. His major argument is that we observe a merger of debt adjustment regimes and insolvency relief. He examines European consumer insolvency systems, based on empirical studies of existing systems, primarily in England and Wales, France, and Germany, and discusses the reasons for the use of consumer insolvency and the limited data on the characteristics of users. He further examines the development of distinct national approaches and outlines common themes and objectives for consumer insolvency in the context of EU measures to create an integrated credit market. He concludes by underlining the absence of systematic social-science knowledge on existing systems and outlining areas for further research.

Johanna Niemi analyses the existing EU approaches to tackle consumer overindebtedness in all their imperfection. The only document at the European level addressing the problem of the over-indebtedness of ordinary people is the Council of Europe Recommendation of 2007, which has as its point of departure the protection of human rights and the development of the justice system. According to Niemi, over-indebtedness in European Union law can and should be approached from several angles. The Insolvency Regulation 2000 does not directly address situations facing the consumer-debtor and leaves it to the discretion of Member States to include or exclude insolvency proceedings for consumer 
debtors regarding the scope of the Regulation. There can be little doubt that the European Union has a legal basis for action in this field, and it has also used its competence in a number of related issues, such as general insolvency law and enforcement of judgments. Niemi argues that, even in the absence of a European Union legal instrument, the Member States should recognise debt adjustment judgments made in another Member State and that there is a need for a comprehensive European regulation in this field.

Thomas Hoffmann focuses on insolvency tourism and the particular role and function of the European Insolvency Regulation (EIR), thereby disclosing the limits of the EIR in fighting insolvency tourism, which runs counter to the logic of the Regulation. Conflicts arise not only in distinguishing genuine and fictional relocations of the Centre of Main Interest (COMI), but also between the effect of discharge and the creditor who did not take into account the possibility of considerably more debtor-friendly discharge abroad when issuing the credit. While relocating a corporate COMI to another Member State which provides better restructuring conditions will generally benefit both creditor and debtor, the effect of discharge in consumer insolvency procedures leads to less balanced results. Even if consumer insolvency tourism is generally not regarded as an abuse of the EIR or of the European freedoms, it may still not respect the interests of both debtors and creditors appropriately. With regard to the prospective revision of the EIR, this paper proposes different approaches to balance the interests of debtors and creditors by normative means.

Claudia Abreu Lopez and Caterina Frade shed light on the impact of the economic crisis on consumer over-indebtedness in Portugal. Contrary to the trend observed in countries with similar indebtedness rates, Portugal has one of the lowest rates of consumer default. Previous studies have identified three strategies that have contributed to the retention of low levels of credit default: reliance on savings, financial support from relatives and friends, and/or cuts in household expenses. These strategies have been widely used for the last decade and have been strained since the beginning of the global financial crisis in 2007. The authors advance the hypothesis that sacrificing living standards is rooted in collective beliefs about the current economic crisis in Portugal, and trust in political and market agents in line with the Theory of Market Anomie. In the current austerity context, with low levels of trust in political institutions and detachment of the economy, consumers will be less prone to sacrifice their remaining savings. In this scenario, credit default and insolvency is expected to rise particularly in those households most exposed to unemployment and social benefits' cuts. This reality puts a huge and growing pressure on the bankruptcy procedure, civil courts, and economic and social policies. Some adjustments should be made to the Portuguese Bankruptcy Code by facilitating and simplifying the bankruptcy regime in order to accommodate the increasing insolvency cases.

In her short narrative "Back to Start: Insolvent and Nevertheless Successful" Anne Koark provides the reader with an account of her experience of bankruptcy under German insolvency law. Thomas Roethe then reconstructs her experience of private insolvency in its structural properties in the "language of the case". Using the methodology of "objective hermeneutics", he analyses the speech of Anne Koark sentence by sentence. Roethe renders descriptive passages of her speech in the shortened form for a better understanding of the argumentative sequences. Private insolvency law in Germany, according to his major argument with regard to the narrative of Anne Koark, paralyses the ambitious entrepreneurial powers of clients who want to resolve the conflict. A better outcome for creditors and debtors could be imaginable if a more sophisticated approach to consumer insolvency is chosen that takes the different starting conditions of the bankrupt consumers into account.

We do hope that the special issue of the Journal of Consumer Law will trigger further research in the field, which is urgently needed and which could pave the way for sound European regulatory action. 